\title{
Police institutions in the face of the pandemic: sensemaking, leadership, and discretion
}

\author{
Gustavo Matarazzo 12 \\ Alan Fernandes 23 \\ Rafael Alcadipani ${ }^{2}$ \\ 1 Instituto Federal de Educação, Ciência e Tecnologia de São Paulo, São Paulo / SP - Brazil \\ 2 Fundação Getulio Vargas / Escola de Administração de Empresas de São Paulo, São Paulo / SP - Brazil \\ 3 Polícia Militar do Estado de São Paulo, São Paulo / SP - Brazil
}

Coping with the COVID-19 pandemic is emerging as one of the greatest recent challenges facing humanity. The police forces are at the front line, among the public institutions specially activated in this emergency. Based on police forces' organizational and professional characteristics, this study discusses strategies to deal with the pandemic through the development of new organizational skills that allow them to change their operating logic from "war against crime" to humanitarian actions. The research points out the need for systemic coordination of police bodies, both among themselves and in the set of other coping measures. In these terms, from the analysis of different experiences, it is proposed to form inter-organizational coordination based on the creation of linguistic and material elements, with the sharing of strategic maps and informational plans. In conclusion, the review of police performance protocols in public health emergencies, including the Public Health Emergency Response Plan of the Ministry of Health, has the capacity to improve its response in the face of the COVID-19 pandemic. Keywords: COVID-19; police; sensemaking.

\section{Organizações policiais frente à pandemia: sensemaking, liderança e discricionariedade}

O enfrentamento da pandemia da COVID-19 desponta como um dos maiores desafios recentes impostos à humanidade. Dentre as instituições públicas especialmente acionadas, as polícias estão posicionadas na linha de frente. A partir de suas características organizacionais e profissionais, discute-se estratégias de enfrentamento à pandemia por meio do desenvolvimento de novas habilidades organizacionais que propiciem alterar suas lógicas de funcionamento de "guerra contra o crime" para ações humanitárias. Assim, aponta-se a necessidade de coordenação sistêmica dos órgãos policiais, tanto entre em si, como no conjunto das demais medidas de enfrentamento. Nesses termos, a partir da análise de experiências diversas, propõe-se a formação de uma articulação interorganizacional fundamentada na criação de elementos linguísticos e materiais, com o compartilhamento de mapas estratégicos e planos informacionais. Para tanto, conclui-se que a revisão de protocolos de atuação das polícias em emergências de saúde pública, a incluir o Plano de Resposta em Emergências em Saúde Pública, do Ministério da Saúde, tem a capacidade de prover avanços nessa questão.

Palavras-chave: COVID-19; polícia; sensemaking.

\section{Organizaciones policiales frente a la pandemia: sensemaking, liderazgo y discrecionalidad}

Hacer frente a la pandemia de COVID-19 se está convirtiendo en uno de los mayores desafíos recientes que enfrenta la humanidad. Entre las instituciones públicas especialmente activadas, la policía está posicionada en primera línea. En función de sus características organizativas y profesionales, las estrategias para hacer frente a la pandemia se discuten mediante el desarrollo de nuevas habilidades organizativas que les permitan cambiar su lógica operativa de "guerra contra el crimen" a acciones humanitarias. Por lo tanto, señala la necesidad de una coordinación sistémica de los cuerpos policiales, tanto entre ellos como en el conjunto de otras medidas de afrontamiento. En estos términos, a partir del análisis de diferentes experiencias, se propone formar una articulación interorganizacional basada en la creación de elementos lingüísticos y materiales, con el intercambio de mapas estratégicos y planes informativos. Por lo tanto, se concluye que la revisión de los protocolos de desempeño policial en emergencias de salud pública, incluido el Plan de Respuesta a Emergencias de Salud Pública, del Ministerio de Salud, tiene la capacidad de proporcionar avances en este tema.

Palabras clave: COVID-19; Policía; sensemaking. 


\section{INTRODUCTION}

The COVID-19 pandemic has emerged as one of the greatest challenges in recent human history. The spread of the virus has led state institutions, particularly those that are directly involved in population management, to implement social distancing with the aim of reducing contagion. In this context, we highlight the role of the public security forces in ensuring governability, especially in relation to complying with the compulsory social distancing measures and the safety of health personnel and equipment, directly related to the prevention of the disease. In Brazil, the police have been investigating the theft and burglary of personal protective equipment against the virus and of tests for the disease, carrying out inquiries into equipment fraud and the rigging of bidding processes, monitoring compliance with the operating rules of economic activities, and even arresting of people who flout the regulations.

The police are one of the frontline categories in the fight against the pandemic that are most vulnerable to contagion. For example, in New York, which saw a major outbreak of the disease, by April 7, 2020, almost 20\% of the police force had been infected by the virus and twelve members had died. Up until now, in Brazil there have not been any surveys regarding this fact. However, a study conducted by the Getulio Vargas Foundation in partnership with the Brazilian Public Security Forum that was published in May 2020 points out that, in São Paulo, 59.7\% of the civil and military police officers are afraid of contracting or having a family member infected by the new coronavirus and, worst of all, just $1 / 3$ of the police in Brazil reported having been given personal protective equipment and training to deal with the pandemic in their daily work.

Police organizations are marked by strong internal cognitive content, a very unique organizational culture and specific occupational cultures (Rubinstein, 1973; Manning, 1977). The current scenario of the COVID-19 pandemic requires a change in perspective in terms of police operations, which are currently focused on the "fighting crime" operating model. In this context, it is felt that there is a need to discuss the adoption of internal management models and practices that are more appropriate and directed at humanitarian actions (Alcadipani, 2020b; Alcadipani, Cabral, Fernandes, \& Lotta, 2020). "Frontline" organizations, such as the police, urgently need to implement organizational changes in order to cope with the pandemic, taking into account a multiplicity of factors, with the highlight here going to biological, social and political ones.

Therefore, this article discusses strategies for tackling the pandemic, on the part of the police, and proposes the development of new organizational skills, promoting efforts to draft an operating model, which coordinates different agencies and ensures a new purpose for the actions of the police corporations. To this end, we organized this article with a section, after the introduction, which focuses on the systemic coordination of the actions of different agencies. Afterwards, we discuss the need to change the police's sensemaking, such as the specific focus on issues of discretion and emotion. Finally, we discuss suggestions for practical elements that the police can adopt to deal with the pandemic.

\section{SYSTEMIC COORDINATION AND INCLUSION OF THE POLICE IN TACKLING THE PANDEMIC}

In studies of bureaucracy, by comparison with other State organizations, the police represent clear examples of isolation, motivated by specific cognitive contents that characterize their own ways of operating (Giacomantonio, 2014; Mastrofski \& Willis, 2010; Monjardet, 1998). In Brazil, for example, 
the civil and military police have a great deal of difficulty in coordinating actions together and in sharing information, which indicates the lack of instruments that facilitate the systemic operation of the different branches of the police, as well as a broader arrangement that connects various state areas. In the current context, in addition to the difficulty of interagency coordination in Brazil one also has to take into account the intrinsic obstacles inherent in fighting the pandemic.

Settings such as the current pandemic require quick and varied decisions, which implies urgent resources and budgets for organizations to take action (Comes, 2016). Responses to contexts like this tend to encounter problems in communication processes, in the exercise of authority and in the development of coordination (Quarantelli, 1988). Furthermore, when we consider communication processes in police organizations, we found that their information technology systems are widely spread and, in general, do not share the same databases (Manning, 2008). In Brazil, dialogue between the Military, Civil and Federal police's data systems is even more unusual.

In order for organizations to act in a coordinated way, it is important that those in management positions share the same strategic map of the context in question. The organizations' directors' and commanders' networking need to be activated with a view to contributing to creating and reinforcing information flows by means of adaptable bureaucratic structures (Stephenson, 2005). We know that police organizations are strongly attached to habits and customs (Manning, 2007, 2008), which can create obstacles to the speed that is necessary at that moment. Therefore, it is our opinion that the work of organizational analysts is very important, bearing in mind the development of environments and devices that are conducive to joint decision-making.

To sum up, the coordination of interorganizational actions is a key aspect to be developed between the different government institutions in order to tackle the pandemic. In Brazil, governments rarely realize that the police can contribute to fighting the pandemic on a daily basis by analyzing population flows, given that the police have instruments for this, and by providing support for health professionals in the organization of care units. The inclusion of police officers in the pandemic's management system depends on the availability of similar information flows from other organizations that are dealing with the disease.

In view of this, the sensemaking of the various organizations that take action to fight the pandemic should share an informational plan that favors interoperability between them. In the case of the police, this effort is even more challenging, as it requires new sensemaking, as we will discuss below.

\section{SENSEMAKING OF THE POLICE FORCES FOR THE PANDEMIC}

Usually, a rational logic is attributed to decision-making by police organizations. However, given the variety of contexts in which the police operate, specific rationales arise that are neither clear nor self-explanatory. In other words, the "rational version" exists, but it is established situationally, in accordance with the contexts in which the decisions are made (Manning, 1977, 2008). This aspect of organizational objectives is often the subject of debate.

The indeterminability of such contexts leads to socio-organizational phenomena that are aimed at reducing these ambiguities (Baran \& Scott, 2010). One way of understanding them is via the notion of sensemaking, which is understood as a way of creating meaning by classifying the flows of experiences into categories (Weick, Sutcliffe, \& Obstfeld, 2005). 
Fighting crime and enforcing the law are two organizational goals for police forces all over the world. This scope of operation is influenced by the organizational and occupational cultures of these institutions (Chan, 1997; Gowricharn \& Çankaya, 2017; Ingram, Terrill, \& Paoline, 2018; Reiner, 2016; Turnbull \& Wass, 2015). That is, fighting crime depends upon symbolic content shared among police officers. However, the symbolic dimension of fighting crime tends to limit the police's reaction to the pandemic, because usually the police have facing risk as a constructed sense, as opposed to what should be done in order to deal with the virus (Alcadipani, 2020a; Alcadipani et al., 2020). Therefore, the chaotic situation resulting from the pandemic requires new frameworks to make sense of organizational processes and actions.

Other countries, where COVID-19 first showed up, making use of the police force's well-established presence, added extra functions to its work, such as: collection of material for tests; structuring logistics to handle specific resources; data collection for the drawing up of strategic actions.

According to Weick et al. (2005), sensemaking is an interactional and cognitive process that begins with chaos, but that makes it possible to transform circumstances into beacons for organizational actions. In the police context, we are dealing with the processes of negotiating the socio-organizational reality (Manning, 2007). In addition to the mixed climate of uncertainty, insecurity and disorientation that is already associated with the extreme nature of police work (Granter, McCann, \& Boyle, 2015), the pandemic brings new aspects, in particular linked to the biological dimension of contagion and the spread of the virus, a dimension that cannot be ignored in establishing meanings for the functioning of the police forces.

The challenges raised by the current scenario demand that police forces understand that this is a moment for humanitarian action, in which the use of force ceases to play a leading role in the police's 'modus operandi' giving way to the construction of negotiated governability. In order that the police officers who are working on the streets fit in with this new profile, devices are needed, which can be understood as the prepared chain of sequences, with the aim being to qualify or transform states of affairs through the mediation of material and linguistic elements (Dodier \& Barbot, 2016). Material elements correspond to the processes and administrative documents that assist and guide the decision-making of "street level bureaucrats" (Lipsky, 2010), in addition to specific protective equipment; and linguistic elements, the set of terms and narratives based on health expertise, which is especially needed at the present time. That is, in chaotic moments, such as the current one, organizations and their leaders need to create devices that help the subjects make sense of situations and contexts. Moreover, it is vital that police officers are trained and understand the risks assumed and the importance of their work in getting though this crisis, by means of clear, scientifically based information flows (Djalante, Shaw, \& DeWit, 2020).

Taking into account the humanitarian nature that the rules for the functioning of organizations and decision-making should adopt, it is important that organizations create linguistic and material elements that clearly outline the contexts, with a view to influencing the formation of meaning of its members. In practical terms, care standards and protocols should be developed, without failing to take into account the atypical situation of people who are infected but who do not have any symptoms (Zhou et al., 2020). At the administrative-bureaucratic level, actions should ensure, for example, a budget for the provision of individual and collective protection materials in the units. 
That said, sensemaking does not mean producing a unique narrative of what is happening, but presents conventional points of support for the development of actions. A number of constraints influence this process, with the role of leaders being fundamental, particularly in police organizations, given their hierarchical and organizational characteristics. We will develop this aspect in the final part of the article.

\section{DISCRETION AND EMOTION: POLICE IN TIMES OF PANDEMIC}

The experiences are irreducible (James, 1904), in other words, they cannot be considered predominantly from a single aspect, be it cognitive or sensory. In our opinion, considering the aforementioned processes as being eminently rational, separating them from the corporeal and emotional dimensions, is a mistake, especially at the present time. Emotions occur in bodies. They are, therefore, dimensions of the creation of meaning, resulting in the influence of emotions on sensemaking processes (Maitlis, Vogus, \& Lawrence, 2013). Therefore, bodily states affect and are affected by the situation; in addition to which, research into embedded cognition shows that cognitive processes are based on human bodies (Hernes \& Maitlis, 2010; Maitlis \& Sonenshein, 2010). In the case of the police forces, all the issues raised should be considered in relation to the body, an important element in the identity of police work (Courpasson \& Monties, 2017).

In view of the above, the body, in the case of the pandemic, starts to be attributed an additional value: it is both the dimension through which the virus proliferates and the disease infects, which, therefore, requires specific care, since it is via the body and the emotions - which will be increasingly put to the test on account of the illness that will affect the police officer, his or her co-workers and family members - that the institutional arrangements need to be built. For these reasons, organizations need to present concerns in relation to physical and mental health at work, especially on account of the increasing contamination rates that will result in a reduction in the workforce.

In addition, arguments that encourage work at any cost cannot be created; a police officer who it is suspected has been contaminated (or who lives with someone who it is suspected has been contaminated) needs to comply in full with the recommendations of health organizations and be furloughed, otherwise he or she poses a risk to other members of the police force as well as to their families. The disease's contagion rate is high (Zhou et al., 2020), and the irresponsible exposure of police officers to contagion can empty entire regions of their active police forces.

Even though we are dealing with organizations in which jobs have a high level of stress (Granter et al., 2015), it is important to highlight that this crisis is an unprecedented one. Therefore, it is likely that many police officers will be infected, which will lead to a decrease in the number of personnel and increase the daily work load related to the established tasks of fighting crime and responding to emergency calls, since, in times like this, in which there is a reconfiguration of flows of people and capital, new forms of conflict and crime tend to emerge, generating new challenges for the corporations.

Police officers are street-level bureaucrats, in other words, they work directly with citizens and have a substantial amount of discretion in their activities (Lipsky, 2010). This discretion is often viewed with suspicion by the supervisory structures and bodies (Cavalcanti, Lotta, \& Pires, 2018). The discretionary space refers to the organizational perspectives, as well as to the relationship between superiors and subordinates; the discretionary action occurs by the way in which the bureaucrats interpret the normative contents (Lotta \& Santiago, 2017). 
In light of this scenario, it is essential that the governing body of police organizations map and, when possible, outline the discretionary space in order to guarantee administrative and legal security for decision making at the local level. Whenever possible, procurement of materials should be carried out by the organizational structures directly involved in tackling the pandemic. Research in the sector shows that instead of such organizational structures performing this task, there are intermediate bureaucratic bodies for this purpose, for example, the centers responsible for purchasing, regional and sectional units and specific structures. The justifications for this scenario of centralization occur on account of the greater possibility of control. However, the players report regarding the lack of speed. In this sense, it is our belief that it is necessary to decentralize the management of part of the budget in order to guarantee catering to the needs of the organizations and of the police officers.

\section{POLICE FORCES AND THE PANDEMIC: WHAT TO DO?}

Based on the above, we ask: what can Brazilian police forces do in a pandemic scenario? Public emergencies require rapid adaptation to unstable conditions, management of distribution of information, bilateral coordination and emerging collective action (Nowell, Steelman, Velez, \& Yang, 2018). In Brazil, the lack of political coordination contributes to the decentralization of the work of the police forces in fighting the virus, and imposes political, material and cultural constraints that immobilize corporations and undermine their work with the population (Alcadipani et al., 2020; Lotta et al., 2020).

Other countries' experiences demonstrate the need for interorganizational coordination in order for the police to mobilize to tackle the pandemic, either by creating coordination mechanisms or by triggering the existing ones (Djalante et al., 2020; Legido-Quigley et al., 2020; Nkengasong \& Mankoula, 2020; Zhao et al., 2020). Brazil has a Public Health Emergency Response Plan (Health Ministry, 2014), which came from the federal government's Health Ministry and was developed to coordinate efforts in the event of public health crises at the national and international levels. The plan envisages the activation of a Public Health Emergency Center (COES) to "[...] promote an organized response by means of the coordination and integration of the players involved" (Health Ministry, 2014, p. 14), with the prior setting up of action protocols for these players. However, this coordination only includes players who are linked to the health field, without the support of law enforcement having been analyzed. This plan is different, for example, to the North American one, which, in cases of a threat to public health, includes institutional instruments for coordinating the police forces with the health authorities (Richards, Rathburn, Brito, \& Luna, 2006).

Therefore, we point out that there is a need to enhance the Public Health Emergency Response Plan, providing it with a scope that includes police work in health measures. This scenario allows for a greater capacity in terms of nationwide coordination of efforts, has the potential to address the problems raised in this study, by conferring new sensemaking to local police arrangements and ensuring aspects of establishing the necessary legitimacy for the actions that are demanded, redirecting the police practices that are already consolidated in their daily lives. However, this is a long-term action, which would mobilize many political players, who, in Brazil, are in a position of divergence and conflict.

In the short term, it is worth observing the examples of other police forces in the world, considering the study "The COVID-19 pandemic and Brazilian police officers" (2020) which shows that 43.9\% of the police do not feel prepared and $24.5 \%$ did not know how to act in the pandemic (Lotta et al., 
2020). In India, in an attitude of a humanitarian nature, the police have been trying to reframe their relationship with people, operating in helping the pandemic's victims and assisting the population in general (Gettleman, Singh, Kim, \& Kumar, 2020). Around the world and also in Brazil, numerous police departments have created protocols regulating how police officers should approach suspects, interrogate witnesses and transport prisoners. The United Kingdom's College of Policing and Interpol have shared specific guidelines and protocols for police action during the pandemic, which address different aspects of the work. The production of short videos showing the protocols in practice can be a quick way of disseminating the use of personal protective equipment, as has been done by São Paulo's Military Police (PMTV, 2020).

Under this logic, it is vital to identify police officers with symptoms who may be infected, in order to avoid contamination of other agents and their families. By carrying out rapid tests on all police professionals, it is possible to identify those who have had contact with the virus and who, for this reason, need to be furloughed from their activities. However, the pandemic has raised the problem of the lack of tests in the world as a whole (Ranney, Griffeth, \& Jha, 2020). The impossibility of access to the tests and the contamination of the agents, after the tests have been carried out, make supplementary measures necessary, such as checking the oxygen levels and temperatures of all the police officers who arrive at work, as has already been done in the US and in Europe. The identifying of a contaminated police officer requires that they be isolated for a period of 14 days. In some places, hotels have been used, because if the disease worsens, the police officer can be attended quickly, avoiding, at the same time, transmitting the virus to his or her family.

It is also important that, as much as possible, the corporations practice social distancing between the police officers in the units and between the police officers and the public; prioritize emergency services and patrolling, but adhering to specific protocols that determine when the police should approach a citizen. Rearranging the tasks so that interaction with the population is carried out virtually is an important protection measure for police officers. In São Paulo, the Civil Police began to register a greater variety of crimes online and also set up an electronic police station for women with attendance provided by students who are in training at the Police Academy. The logic should be that police officers only go to their workplaces when necessary. In addition, there are police forces outside Brazil that have set up police task forces aimed at covering for colleagues who have been furloughed on account of the disease. It is important to suspend all of the institutions' face-to-face ceremonies, such as São Paulo's Military Police has done. In addition, there are police forces that are altering work shifts with the aim of helping social distancing and, by means of this, reduce the number of people sharing spaces at the same time.

Tackling crises highlights the roles of organizational leaderships, as they influence the conditions that define situations and the ways to understand them (Whittle, Housley, Gilchrist, Mueller, \& Lenney, 2015), as well as help in the sensemaking process within organizations. Studies indicate that the creation of meaning by leaders is a process that does not always address the speed of the facts experienced; of course, building consensus and raising the awareness of the individuals involved requires a certain amount of time (Combe \& Carrington, 2015). The discussion in relation to the role of the leaderships is even more fundamental in police organizations, which are based on hierarchies.

The organizational and political leaders should fine-tune their arguments and base themselves on more consolidated fields of expertise, supported by technology and science ("Coronavirus: three 
things all governments and their science advisers must do now", 2020). In this way, the leaders will find better conditions for creating new adaptive contexts to the needs that will arise with the development of the pandemic, supporting the organizational changes. With regard to this, the profusion of fake news and/or information that has little credibility on social media creates difficulties for the leaders and for the cognitive construction of new environments.

Therefore, the leaders have a key role to play in guiding the frameworks, without doubts or confusion about the actions. The police forces that are responding better to the challenge are those whose internal leaders have assumed a leading role: firstly, by recognizing the seriousness of the disease for police forces and of the need to work in a different way in light of the pandemic, and afterwards, by giving the example of adopting security protocols and frequently communicating to the police the path that they should take. In this way, police leaders need to make it clear that the moment of the COVID-19 pandemic is an exceptional one: in this situation, only police emergencies should mobilize the efforts of their institutions, social distancing should be taken seriously by police organizations. In addition, their leaders need to direct their organizations to work much more as humanitarian support institutions than as instruments to fight crime.

\section{FINAL CONSIDERATIONS}

It appears that the COVID-19 pandemic represents the greatest challenge that has faced humanity since World War II. It provides us with the experience of the uncertainty of the world and our relationship with nature (Dewey, 1958; James, 1904). These issues clash brutally with the operating rationale of the organizations, particularly with regard to the perspectives of the rationality, objectives and senses constructed organizationally.

In this article, we attempt to demonstrate that the work of the police should be changed in order to tackle the global pandemic, which requires efforts so that the police organizations are added to the interagency coordination. To this end, we point out that the well-established structures of these organizations need varied support.

However, in addition to the question of management of authority in the organization, the meanings that guide the necessary changes, and the construction of new material and linguistic devices that promote new frameworks for police action are also important. Police organizations need to change their operating mindset, moving from the notion of "a war against crime" to that of humanitarian actions (Alcadipani, 2020c).

Thus, it is imperative that organizations adjust themselves by means of the same informational plan, presenting narratives that are in line with each other, developing organizational methods and meanings that establish public security as a humanitarian action.

Emotions and discretion are aspects to be taken into account, particularly by those professionals who are working on the front line in fighting the pandemic. Therefore, it is our belief that these organizations will become tools for tackling this crisis and can glimpse in this situation a window of opportunity to establish new relationships with their public. As the case of India illustrates, acting to promote humanitarian action can bring the police closer to society, which is a key element for the proper functioning of any public security policy. 


\section{REFERENCES}

Alcadipani, R. (2020a). Pandemic and macho organizations: wakeup call or business as usual? Gender, Work \& Organization, Early view, 1-13. Retrieved from https://doi.org/10.1111/gwao.12466

Alcadipani, R. (2020b, March 05). The coronavirus and the impact for public security. Estadão. Retrieved from https://politica.estadao.com.br/blogs/gestaopolitica-e-sociedade/o-coronavirus-e-os-impactospara-a-seguranca-publica/

Alcadipani, R. (2020c, March 20). The coronavirus and the collapse of the public security system. Estadão. Retrieved from https://politica.estadao. com.br/blogs/gestao-politica-e-sociedade/ocoronavirus-e-o-colapso-do-sistema-de-segurancapublica/

Alcadipani, R., Cabral, S., Fernandes, A., \& Lotta, G. (2020, June). Street-Level bureaucrats under COVID-19: police officers' responses in constrained settings. Administrative Theory \& Praxis, 1-10. Retrieved from https://doi.org/10.1080/10841806. 2020.1771906

Baran, B. E., \&Scott, C. W. (2010, January). Organizing ambiguity: a grounded theory of leadership and sensemaking within dangerous contexts. Military Psychology, 22 (Suppl. 1), S42-S69. Retrieved from https://doi.org/10.1080/08995601003644262

Cavalcanti, S., Lotta, G. S., \& Pires, R. R. C. (2018). Contribuições dos estudos sobre burocracia de nível de rua. In R. Pires, G. S. Lotta, \& V. E. Oliveira (Orgs.), Burocracia e políticas públicas no Brasil: interseções analíticas (pp. 227-246). Brasília, DF: Ipea/Enap. Retrieved from http://repositorio.enap. gov.br/bitstream/1/3247/1/livro_Burocracia e políticas públicas no Brasil - interseções analíticas. pdf

Chan, J. B. L. (1997). Changing police culture. Policing in a multicultural society. Cambridge, UK: Cambridge University Press.

Combe, I. A., \& Carrington, D. J. (2015). Leaders' sensemaking under crises: emerging cognitive consensus over time within management teams. Leadership Quarterly, 26(3), 307-322. Retrieved from https://doi.org/10.1016/j.leaqua.2015.02.002

Comes, T. (2016, March). Cognitive biases in humanitarian sensemaking and decision-making lessons from field research. Proceedings of 2016 IEEE International Multi-Disciplinary Conference on Cognitive Methods in Situation Awareness and Decision Support, (pp. 56-62), San Diego, CA. Retrieved from https://doi.org/10.1109/ COGSIMA.2016.7497786

Coronavirus: three things all governments and their science advisers must do now. (2020, March 17). Nature, 579(7799), 319-320. Retrieved from https:// doi.org/10.1038/d41586-020-00772-4

Courpasson, D., \& Monties, V. (2017). "I am my body". Physical selves of police officers in a changing institution. Journal of Management Studies, 54(1), 32-57. Retrieved from https://doi.org/10.1111/ joms. 12221

Dewey, J. (1958). Experience and nature. New York, NY: Dover.

Djalante, R., Shaw, R., \& DeWit, A. (2020, April). Building resilience against biological hazards and pandemics: COVID-19 and its implications for the Sendai Framework. Progress in Disaster Science, 6, 100080. Retrieved from https://doi.org/10.1016/j. pdisas.2020.100080

Dodier, N., \& Barbot, J. (2016). La force des dispositifs. Annales. Histoire, Sciences Sociales, 71(02), 421-448. Retrieved from https://doi. org/10.1353/ahs.2016.0064

Gettleman, J., Singh, K. D., Kim, C., \& Kumar, H. (2020, June 01). How India's Police Used a Pandemic to Boost Its Image. NYTIMES. Retrieved from https://www.nytimes.com/video/ world/100000007141490/-india-police-pandemiccoronavirus.html ?action $=$ click \&gtype $=$ vhs \&ver sion $=$ vhs - heading $\&$ module $=$ vhs $\&$ region $=$ titlearea $\&$ cview $=$ true $\& \mathrm{t}=4$

Giacomantonio, C. (2014). A typology of police organizational boundaries. Policing and Society, 24(5), 545-565. Retrieved from https://doi.org/10.1 080/10439463.2013.784302

Gowricharn, R., \& Çankaya, S. (2017). Policing the Nation: acculturation and streetlevel bureaucrats in professional life. Sociology, 51(5), 1101-1117. Retrieved from https://doi. org/10.1177/0038038515601781

Granter, E., McCann, L., \& Boyle, M. (2015). Extreme work/normal work: intensification, storytelling and 
hypermediation in the (re)construction of 'the New Normal.' Organization, 22(4), 443-456. Retrieved from https://doi.org/10.1177/1350508415573881

Hernes, T., \& Maitlis, S. (2010). Process, sensemaking, and organizing: an introduction. In T. Hernes \& S. Maitlis (Eds.), Process, Sensemaking, \& Organizing (Perspectiv, pp. 27-37). New York, NY: Oxford University Press.

Ingram, J. R., Terrill, W., \& Paoline, E. A. (2018). Police culture and officer behavior: application of a multilevel framework. Criminology, 56(4), 780811. Retrieved from https://doi.org/10.1111/17459125.12192

James, W. (1904). The world of pure experience. The Journal of Philosophy, Psychology and Scientific Methods, 1(20), 533-543.

Latour, B. (2012). Reagregando o social: uma introdução à teoria do Ator-Rede. Salvador, BA: EDUFBA; EDUSC.

Legido-Quigley, H., Mateos-García, J. T., Campos, V. R., Gea-Sánchez, M., Muntaner, C., \& McKee, M. (2020). The resilience of the Spanish health system against the COVID-19 pandemic. The Lancet Public Health, 5(5), e251-e252. Retrieved from https://doi. org/10.1016/S2468-2667(20)30060-8

Lipsky, M. (2010). Street-level democracy: dilemmas of the individual in public services (30th anniv.). New York, NY: Russell Sage Foundation.

Lotta, G., \& Santiago, A. (2017). Autonomia e discricionariedade: matizando conceitos-chave para o estudo da burocracia. BIB, 1(83), 21-42.

Lotta, G., Sobral, I., Corrêa, M., Alcadipani, R., \& Bueno, S. (2020, May 18). A pandemia de Covid-19 e os policiais brasileiros (Nota técnica). São Paulo, SP: Fórum Brasileiro de Segurança Pública. Retrieved from https://forumseguranca.org.br/ publicacoes_posts/a-pandemia-de-covid-19-e-ospoliciais-brasileiros/

Maitlis, S., \& Sonenshein, S. (2010). Sensemaking in crisis and change: inspiration and insights from Weick (1988). Journal of Management Studies, 47(3), 551-580. Retrieved from https://doi.org/10.1111/ j.1467-6486.2010.00908.x

Maitlis, S., Vogus, T. J., \& Lawrence, T. B. (2013). Sensemaking and emotion in organizations.
Organizational Psychology Review, 3(3), 222-247. Retrieved from https://doi. org/10.1177/2041386613489062

Manning, P. K. (1977). Police work: the social organization of policing. Cambridge, UK: MIT Press.

Manning, P. K. (2007). A dialectic of organisational and occupational culture. In M. O'Neill, M. Marks, \& A.-M. Singh (Eds.), Police occupational culture: new debates and directions (pp. 47-84). Oxford, UK: JAI Press. Retrieved from https://doi.org/10.1016/ S1521-6136(07)08002-5

Manning, P. K. (2008). The technology of policing: crime mapping, information technology, and the rationality of crime control. New York, NY: New York University Press.

Mastrofski, S. D., \& Willis, J. J. (2010). Police organization continuity and change: into the twentyfirst century. Crime and Justice, 39, 55-144. Retrieved from https://doi.org/10.1086/653046

Ministério da Saúde. Secretaria de Vigilância em Saúde. Departamento de Vigilância em Saúde Ambiental e Saúde do Trabalhador. (2014). Plano de Resposta às Emergências em Saúde Pública. Brasília, DF: Author.

Monjardet, D. (1998). Elementos de análisis de los sistemas policiales. Revista Catalana de Seguretat Pública, 2, 179-194.

Nkengasong, J. N., \& Mankoula, W. (2020). Looming threat of COVID-19 infection in Africa: act collectively, and fast. The Lancet, 395(10227), 841-842. Retrieved from https://doi.org/10.1016/ S0140-6736(20)30464-5

Nowell, B., Steelman, T., Velez, A. L. K., \& Yang, Z. (2018). The structure of effective governance of disaster response networks: insights from the field. American Review of Public Administration, 48(7), 699-715. Retrieved from https://doi. org/10.1177/0275074017724225

PMTV. (2020, April 17). Atuação da PMESP em tempos de COVID-19. Youtube. Retrieved from https://www.youtube.com/watch?v=T2Xn21 xowP0

Quarantelli, E. L. (1988). Disaster crisis management. Journal of Management Studies, 25(4), 373-385. Retrieved from https://doi. org/10.1111/j.1467-6486.1988.tb00043.x 
Ranney, M. L., Griffeth, V., \& Jha, A. K. (2020). Critical supply shortages - the need for ventilators and personal protective equipment during the Covid-19 pandemic. New England Journal of Medicine, 382(18), e41(1)-e41(3). Retrieved from https://doi.org/10.1056/NEJMp2006141

Reiner, R. (2016, December 05). Is police culture cultural? Policing, (Opinion), 11(3), 236-241. Retrieved from https://doi.org/10.1093/police/ paw046

Richards, E. P., Rathburn, K. C., Brito, C. S., \& Luna, A. (2006). The Role of Law Enforcement in Public Health Emergencies. Washington, DC: U.S. Department of Justice.

Rubinstein, J. (1973). City Police. New York, NY: Farrar, Straus and Giroux.

Stephenson, M., Jr. (2005). Making humanitarian relief networks more effective: operational coordination, trust and sense making. Disasters, 29(4), 337-350. Retrieved from https://doi. org/10.1111/j.0361-3666.2005.00296.x

Turnbull, P. J., \& Wass, V. (2015). Normalizing extreme work in the Police Service? Austerity and the inspecting ranks. Organization, 22(4), 512-529. Retrieved from https://doi. org/10.1177/1350508415572513

Weick, K. E., Sutcliffe, K. M., \& Obstfeld, D. (2005). Organizing and the Process of Sensemaking. Organization Science, 16(4), 409-421. Retrieved from https://doi.org/10.1287/orsc.1050.0133

Whittle, A., Housley, W., Gilchrist, A., Mueller, F., \& Lenney, P. (2015). Category predication work, discursive leadership and strategic sensemaking. Human Relations, 68(3), 377-407. Retrieved from https://doi.org/10.1177/0018726714528253

Zhao, W., Zhang, J., Meadows, M. E., Liu, Y., Hua, T., \& Fu, B. (2020, June 15). A systematic approach is needed to contain COVID-19 globally. Science Bulletin, 65(11), 876-878. Retrieved from https:// doi.org/10.1016/j.scib.2020.03.024

Zhou, F., Yu, T., Du, R., Fan, G., Liu, Y., Liu, Z., ... Cao, B. (2020, March 09). Clinical course and risk factors for mortality of adult inpatients with COVID-19 in Wuhan, China: a retrospective cohort study. The Lancet, 395, 1054-1055. Retrieved from https://doi.org/10.1016/S0140-6736(20)30566-3

\section{Gustavo Matarazzo}

https://orcid.org/0000-0002-4640-3863

Doing post-doctoral studies in Business Administration at the Escola de Administração de Empresas de São Paulo (EAESP) of the Fundação Getulio Vargas (FGV); Professor at Instituto Federal de Educação, Ciência e Tecnologia de São Paulo (IFSP) Capivari Campus. E-mail: gustavo.matarazzo@ifsp.edu.br

\section{Alan Fernandes}

https://orcid.org/0000-0003-1364-3868

Studying for a Ph.D. in Business Administration at the Escola de Administração de Empresas de São Paulo (EAESP) of the Fundação Getulio Vargas (FGV); a Major in the State of São Paulo’s Military Police.

E-mail: alan@policiamilitar.sp.gov.br

\section{Rafael Alcadipani}

https://orcid.org/0000-0001-5132-5380

Ph.D. in Management Sciences from Manchester Business School; Full professor at the Escola de Administração de Empresas de São Paulo (EAESP) of the Fundação Getulio Vargas (FGV). E-mail: rafael.alcadipani@fgv.br 